\title{
DID WORKERS PAY FOR THE PASSAGE \\ OF WORKERS' COMPENSATION LAWS?
}

\author{
Price V. Fishback \\ Shawn Everett Kantor
}

Working Paper No. 4947

\section{NATIONAL BUREAU OF ECONOMIC RESEARCH 1050 Massachusetts Avenue \\ Cambridge, MA 02138 \\ December 1994}

Earlier versions of this paper were presented at the 1992 Cliometrics Conference, 1992 Social Science History Conference, and 1992 Western Economic Association meetings and in seminars at the University of Arizona, California Institute of Technology, Columbia University, Cornell University, and University of California, Davis and Los Angeles. We thank numerous participants at these meetings and seminars for their valuable comments. In addition, we thank Lawrence Katz, James Ratliff, Stanley Reynolds, John Wooders, and two anonymous referees for helpful suggestions. This research has been supported by the Earhart Foundation (Fishback), the University of Arizona Foundation (Kantor), and the National Science Foundation, Grant No. SBR-9223058. This paper is part of NBER's research programs in the Development of the American Economy and Labor Studies. Any opinions expressed are those of the authors and not those of the National Bureau of Economic Research.

(0) 1994 by Price V. Fishback and Shawn Everett Kantor. All rights reserved. Short sections of text, not to exceed two paragraphs, may be quoted without explicit permission provided that full credit, including () notice, is given to the source. 


\title{
DID WORKERS PAY FOR THE PASSAGE \\ OF WORKERS' COMPENSATION LAWS?
}

\begin{abstract}
Market responses to legislative reforms often mitigate the expected gains that reformers promise in legislation. Contemporaries hailed workers' compensation as a boon to workers because it raised the amount of post-accident compensation paid to injured workers. Despite the large gains to workers, employers often supported the legislation. Analysis of several wage samples from the early 1900 s shows that employers were able to pass a significant part of the added costs of higher post-accident compensation onto some workers in the form of reductions in wages. The size of the wage offsets, however, were smaller for union workers.
\end{abstract}

Price V. Fishback

Department of Economics

University of Arizona

Tucson, AZ 85721

and NBER
Shawn Everett Kantor

Department of Economics

University of Arizona

Tucson, AZ 85721

and NBER 


\section{INTRODUCTION}

During the twentieth century there has been a proliferation of social protection programs that are at least partially financed through employer mandates. Current proposals mandating that employers provide their workers with health insurance is not a novel idea, but a continuation of a longer trend which includes such programs as unemployment insurance, social security, Medicare, and family-leave requirements. The first large-scale program mandating employer provision of insurance benefits was workers' compensation, which was introduced at the state level primarily during the 1910s. Workers' compensation shifted the tort rules governing workplace accidents from negligence liability to a form of strict liability whereby the employer was expected to replace up to two-thirds of the workers' lost earnings for all serious accidents occurring in the workplace. This change in the liability rules led to a substantial rise in the post-accident benefits that in jured workers received.

Social reformers widely hail the introduction of social insurance programs as bonuses to workers, presuming that the substantial increase in de jure benefits represents a redistribution of income from employers to workers. Numerous studies suggest, however, that employers are able to pass on at least part of the cost of these employer-mandated benefits back to workers. For example, Moore and Viscusi [1990, p. 24] and Gruber and Krueger [1991] have found that increases in workers' compensation benefits in the 1970 s and 1980 s led to substantial wage offsets for workers. In some cases, these wage reductions were larger than the expected value of the new benefits that workers received. Further, Gruber [1994] found that employers were able to shift the cost of state and federal requirements that they provide comprehensive maternity coverage in health insurance plans in the late 1970 s onto those workers who would have generated the increased insurance costs. These results suggest that the de facto redistribution of income caused by the employer-mandated benefits are quite different from the redistribution promised in the laws.

In this paper we examine the impact that the passage of workers' compensation laws had 
[Kantor and Fishback, 1994; Castrovinci, 1976].

The presence of substantial wage offsets provides new insights into the political support for workers' compensation. Nonunion workers essentially "bought" the more certain and generous payments under workers' compensation through a drop in their wages, while some unionized workers experienced much smaller and statistically insignificant wage of fsets. Many employers supported the passage of workers' compensation because they could anticipate passing a substantial portion of the costs onto their workers. Thus, they not only received the benefits described by earlier scholars, but they also bore a much smaller de facto share of the costs than was originally presumed.

The remainder of the paper discusses the substantial change in post-accident benefits that workers received with the introduction of workers' compensation. We then examine the impact of the change in post-accident benefits in three major industries between 1907 and 1923: the coal industry, the lumber industry, and the building trades.

\section{THE NATURE OF ACCIDENT COMPENSATION BEFORE AND AFTER WORKERS'}

\section{COMPENSATION}

De jure reparation for job-related accidents before workers' compensation was determined according to the common law rules of negligence. Under negligence liability an employer was expected to exercise "due care" in protecting his employees against workplace hazards." The employer was legally obligated to hire "suitable and sufficient" co-workers; to establish and to enforce proper rules of conduct within the work environment; to provide a safe workplace; to furnish safe equipment; and to provide employees with warnings and suitable instructions in the face of dangerous working conditions. In order to collect accident compensation, an injured worker bore the burden of proving that his employer had failed to exercise due care in carrying out these duties and that the employer's negligence was the proximate cause of the injury. Even if an employer were found to be negligent, he could escape liability through three common law 
on wage rates through an analysis of wage samples drawn from the period surrounding the adoption of the legislation. We focus on three relatively dangerous industries: coal mining, lumber milling, and the unionized building trades. Analyzing the economic impact of workers' compensation provides a unique opportunity to provide a comparative assessment of how wages respond to legislative shocks under quite different institutional frameworks. Over the course of the twentieth century, the relationship between workers and employers have increasingly become "contractual" and the government has increased its regulation of labor markets and the scope of mandated employer-provided benefits. Comparisons of our results with those of Moore and Viscusi and Gruber and Krueger show that the wage of fets in response to rising post-accident benefits were quite similar in modern labor markets and in past nonunion labor markets. Institutional differences appear to be important because the wage offsets in unionized sectors appear to have been important, however, because the wage of fsets that we find for the unionized sector were much smaller than those for the nonunionized sector.

Understanding how wages adjusted in response to the large increase in post-accident compensation associated with the introduction of workers' compensation helps to resolve a major puzzle in the political economy of the origins of the legislation. Workers received substantial increases in their expected benefits, yet most employers supported the workers' compensation laws. Lubove [1967] and Weinstein [1967] claim that employers supported the legislation as a means of buying labor peace, as a way to stem the tide of court rulings that increasingly favored injured workers, and as a way to reduce the costs of settling accident claims. None of these explanations seems completely satisf ying because none seems to offer large enough benefits to offset the overwhelming increase in post-accident compensation that employers accepted. ${ }^{1}$ Also surprising is that workers' support for workers' compensation was not as complete and widespread as would be anticipated from the large increase in post-accident benefits. In fact, unions in some states split on the issue and Missouri workers, when given an opportunity to vote on workers' compensation in referenda, displayed large-scale indifference to the compensation legislation 
injured workers collected nothing as a result of their occupational injury [Kantor and Fishback, 1993]. For those workers receiving some positive amount from their employers, compensation ranged from an average of 24 to 227 percent of the lost earnings and medical expenses associated with the industrial accident. That some workers were receiving awards in excess of their monetary losses suggests that employers paid some workers for their "pain and suffering," which was remunerative as an economic loss under the common law [Posner 1972, p. 46].

In addition to any post-accident payments, workers received pre-accident compensation in the form of risk premiums in wage rates. Fishback and Kantor [1992] found some evidence of accident-risk premiums in hedonic wage regressions on samples of individual workers from several states between 1884 and $1903 .^{6} \mathrm{Kim}$ and Fishback [1993] found that railroad workers in jobs with higher fatal and nonfatal accident risk received higher wages during the period from 1892 to 1909. Similar to the findings here, as post-accident compensation for fatal accidents rose after the passage of the Federal Employers' Liability Acts of 1906 and 1908, the fatal-accident risk premium diminished.

Workers' compensation laws dramatically changed the nature of post-accident compensation by mandating that employers remunerate all workers for their injuries arising "out of and in the course of employment. ${ }^{m 7}$ The laws were enacted rapidly across the United States in the 1910s. Within a decade, 44 states had adopted compensation legislation and by 1930 only Arkansas, Florida, Mississippi, and South Carolina had yet to enact a law. As Harry Weiss [1935, p. 575] noted, "No other kind of labor legislation gained such general acceptance in so brief a period in this country."

The shift to workers' compensation raised the expected amount of post-accident compensation in two important ways. First, the percentage of workers and their families receiving no compensation fell dramatically. For example, Conyngton's [1917, p. 109] survey of families of fatally injured workers in Ohio and Connecticut in 1915 revealed that only 2.9 and 9.4 percent, respectively, received no benefits under workers' compensation. Further, in the cases 
defenses: that the employee had assumed the risks associated with the employment (assumption of risk); that a co-worker (fellow servant) had caused the accident; or that the worker himself was negligent or had not exercised due care (contributory negligence). ${ }^{3}$

Proving the employer's negligence and overcoming the three defenses in a court of law was a costly and formidable task. Pushing a suit through the court system of ten led to delays of two to five years between the date of the accident and a final court decision. In addition, there was a great deal of uncertainty about the results of the decision. As a result, the vast majority of workers sold their "rights of action" in out-of-court settlements [Downey 1917, p. 583]. Evidence from Minnesota [1909-1910, pp. 166-169] prior to the adoption of workers' compensation suggests that 89 percent of the fatal accident cases, 78 percent of permanent partial disability cases, and 99 percent of the temporary disabilities were settled without the courts.

As many states were debating the adoption of workers' compensation in the early 1910 s, they commissioned studies of the nature of workplace accident compensation under the negligence system in their respective states. Evidence drawn from 7 of these studies, summarized in Table I, reveals that families of married fatal accident victims bore the preponderance of the financial burden of an industrial accident. The studies, which exclude railroad workers, reveal that the percentages receiving no compensation at all ranged from $\mathbf{2 2 . 2}$ percent of Minnesota families in 1909-1910 to as high as 60.9 percent among men killed in Illinois before 1911. In the last column of the table we report the mean ratio of death benefits to annual earnings; the families receiving no compensation are included in the calculation. The mean ratio of compensation for fatalities ranged from a low of 38.3 percent of annual earnings in Pennsylvania to 119.5 percent in Minnesota. ${ }^{4}$ On average, however, the available evidence suggests that about 43 percent of the families of fatal industrial accident victims would have received no compensation at all. Ex ante, the typical family's expected compensation from the employer of a fatal accident victim would have been approximately 56 percent of one year's earnings.

Among non-fatal accident victims, the studies found that between 9.1 to 72.9 percent of 
where the workers received nothing, there was a significant question about whether the accident occurred in the workplace. These percentages are substantially lower than even the lowest percentages for the negligence liability system presented in Table I. Second, for those families that received a positive amount of compensation for the death of their primary wage earners, the payments were significantly higher under workers' compensation than under negligence liability. The information underlying the averages from Table I implies that the families that received a positive amount of compensation expected only about one year's earnings under negligence liability. Under workers' compensation, however, their expected benefits would have more than doubled. For example, in Ohio in 1915 the families receiving death benefits received a stream of payments with a present value discounted at 10 percent of $\$ 2,394$, which was 2.88 times average annual earnings (weekly wage of $\$ 16.65$ times 50 weeks). In Connecticut the present value of compensation was $\$ 1,747$, or 2.33 times annual earnings (weekly wage of $\$ 15.01$ times 50 weeks) [Conyngton 1917, pp. 110-170]. The workers' compensation payments are reported as discounted values because the structure of payments of ten differed between the two legal regimes. While most payments under negligence liability were lump sums, nearly every workers' compensation state paid families a weekly payment over an extended period of time. ${ }^{8}$

The accident benefits paid out under workers' compensation were determined by statutory provisions that varied by state and within states over time. The laws typically established that workers (or their families) would be paid a percentage of their weekly wage for a maximum number of weeks and most states fixed maximum amounts of total compensation. For example, benefits in Connecticut in $\mathbf{1 9 1 5}$ provided families of fatal accident victims weekly payments equal to 50 percent of the workers' wage for up to 312 weeks, and weekly benefits could not be lower than $\$ 5$ a week or higher than $\$ 10$ a week.

Non-fatal accidents were separated into three major categories -- permanent total disability, permanent partial disability, and temporary disability -- and the compensation for each followed the general pattern of that for fatal accidents. During his disability the worker was paid 
occurrence, and then we summed the four expected compensation figures. ${ }^{9}$ The index numbers in Table II represent expected accident compensation as a percentage of annual earnings (national average weekly wage times 52) at the end of the year listed.

The table shows the pace of the introduction of workers compensation since the first entry for each state represents the first year the law went into effect. The pace of adoption was relatively rapid, with all but 6 states adopting the law by the end of 1923 . Southern states generally lagged behind the rest of the country in adopting the legislation. The generosity of benefits varied widely across states within any one year. In 1923, for example, the benefits ranged from a low of 0.82 percent of annual income in Virginia to a high of 2.16 percent in North Dakota. Each states relative position also fluctuated from year to year. For example, Washington and Oregon both ranked high in terms of generosity when they first introduced their laws, but they established fixed benefits for all workers. Their rankings fell sharply throughout the 1910s, as inflation and wage increases eroded the generosity of the fixed amounts.

The table also shows how accident benefits changed over time within states. In most states the index of expected compensation fell during the second half of the 1910s. The rapid rise in wages during World War I of ten caused benefit levels to hit statutory maximums, thus causing the relative generosity of the payments to lag. After some delay most states raised their maximums between 1919 and 1923. The pattern of benefits in Texas provides a good example of the effects of inflation on expected compensation when the states were slow in boosting the maximums. When the law was adopted in 1913, it provided expected benefits valued at 1.62 percent of annual earnings and the state did not change the maximum allowable benefit until 1923. By 1920, wage inflation had caused relative benefits in that year to be only 66 percent of what they were when the law was first enacted.

Finally, it should be noted that while post-accident compensation had risen dramatically under workers' compensation, the laws only allowed workers or their families to collect a fraction of their lost wages. For example, the present value of the wages lost for a fatal accident would 
some percentage of his weekly wage, subject to statutory minimum and maximum payments, for a maximum number of weeks. For permanent partial disabilities, such as the loss of an arm, hand, or leg, states typically provided a schedule of the maximum number of weeks the worker could collect compensation for his particular accident. For example, a worker who lost his hand in Connecticut in 1915 was guaranteed 50 percent of his weekly wage for 156 weeks, subject to the same minimum and maximum weekly benefits as paid for fatal accidents.

The evidence from Conyngton's [1917] surveys from Ohio and Connecticut in 1915 suggest that families generally received the benefits they were entitled to by law. For Ohio, the families' actual death benefits were on average equal to 98.8 percent of the weekly payment that we estimated the families should have received using the statutory rules and each worker's reported weekly wage. In fact, 46 percent of the actual payments were the same as predicted by the statute, 34 percent were slightly higher, and 20 percent were slightly lower. In Connecticut, the actual payments averaged 99.9 percent of the predicted payments based on the statute. Therefore, cross-state comparisons of estimated workers' compensation payments using the statutory rules should give a reasonable measure of the actual amounts that injured workers and their families received.

To show how workers' compensation benefits varied across states and time, Table II presents an index of the relative generosity of workers' compensation benefits for each state from 1910 to 1923. The former year represents the first year of adoption and the latter year is the last year covered in the data analyzed below. For each year and state we computed the present value (assuming a discount rate of 10 percent) of the stream of payments a worker or his family would have received for each of the four categories of industrial accidents given the particular rules governing workers' compensation in each state. The index is calculated assuming that the hypothetical worker in each state earned the national average manufacturing wage. Since our goal is to report a measure that reflects the worker's expected compensation from all workplace accidents, we weighted each of the four types of accident benefits by its probability of 
have amounted to approximately 8 to 10 times annual earnings for a 30 year old worker. The present value of the death benefits in even the most generous states at the time did not exceed 4.5 times the deceased's annual earnings. Thus, while workers' compensation dramatically increased the amount and probability of receiving compensation if a workers were injured in the course of employment, like other social insurance systems, it did not promise full wage replacement.

\section{THE IMPACT OF WORKERS' COMPENSATION ON WAGES}

Moore and Viscusi [1990, pp. 24-25] summarize a set of studies using modern evidence that show that increases in workers' compensation benefit levels are associated with reductions in wage rates. Similarly, Gruber and Krueger [1991] find that employers are able to pass a substantial portion of their workers' compensation insurance costs onto workers through lower wages. If labor markets in the early 1900 s operated in a similar fashion, the sharp jump in postaccident compensation when states moved from negligence liability to workers' compensation potentially could have been of fset by a decline in risk premiums implicit in wages.

To examine how the wages of workers adjusted to the introduction of workers' compensation, we have constructed three separate panel data sets for relatively dangerous industries in the early 1900s. The first sample covers hourly wage rates from payrolls collected by the U.S. Bituminous Coal Commission. The sample contains state averages for 10 jobs from the 23 leading coal producing states at the end of each year from 1911 to 1922 . The second sample is hourly earnings collected from payrolls by the U.S. Bureau of Labor Statistics for 10 different jobs in the lumber industry for the years 1910-1913, 1915, 1921, and 1923 in the 23 lumber producing states. The third sample is the wage scales listed in union contracts in the building trades for 13 occupations in 77 cities for each year between 1907 and $1913 .^{10}$ All three data sets allow examination of differences across states and over time during the period when nearly all the workers' compensation laws were adopted.

We estimated reduced-form, weighted least squares wage regressions with the hourly wage 
(in constant 1890-1899 dollars) as the dependent variable. ${ }^{11}$ The reduced form contains variables affecting the employers' wage offer function and the workers' wage acceptance function. The employers' of fers were influenced by fluctuations in the product market and in worker productivity. Variables affecting the workers' wage acceptance function include the extent of post-accident benefits, measures of restrictions on working time, and the accident rate (which was available at the state level only for the coal sample). Workers seek higher wages as compensation for lower accident benefits, more restrictions on working time, and higher accident rates. For the coal industry analysis we were also able to include information on strikes and union strength, which also might have affected the wages that workers sought. State dummy variables (city dummies for the building trades) control for geographic differences in labor market conditions, such as differences in the cost of living and other labor laws specific to individual states. Year dummies control for labor market differences specific to each year, like the government's greater control of markets during World War I. Occupation dummy variables in all of the regressions control for skill differences and differences in the supply and demand conditions for those particular jobs.

The regression coefficients presented in Table III are generally consistent with the findings of other wage studies. Wage rates were positively related with product prices in the coal and lumber samples, while increases in building activity (measured by the real value of building permits per capita) were associated with higher wages in the building trades. ${ }^{12}$ Output per man hour was positively associated with wages in both the coal and lumber industries. In all of the estimations, the coefficients of the occupation dummy variables suggest that higher skilled workers earned relatively higher wages. Limitations on working time, as measured by full-time hours, were offset by higher wages in the lumber sample. ${ }^{13}$ Unions and strike activity were associated with higher wages in the coal industry, although the union coefficient was statistically insignificant. The remainder of the paper focuses on the impact of changes in post-accident benefits on wage rates. 
The primary focus of the paper is to determine the impact of workers' compensation laws and changes in post-accident compensation on wage rates. A common method for testing the impact of shifts in legal regimes on wages is to use a standard dummy variable taking the value one for states and years in which the law is in effect, and zero otherwise. Using this test, the coefficients in Table III reveal that workers' compensation was associated with a decline in wage rates in two of the three industries. In coal mining the presence of a workers' compensation law was associated with a statistically significant 2.16 percent decline in hourly earnings when evaluated at the mean hourly earnings. Similarly, the lumber industry wage of fset was 1.6 percent and statistically significant. In the building trades, however, the decline was small, 0.33 percent, and not statistically different from zero. ${ }^{14}$

Using the dummy variable provides only a rough estimate of how workers' compensation affected wages because the adoption of the laws were associated with more complex changes in accident benefits than a zero-one variable can capture. A dummy variable fails to represent the substantial variation in accident compensation paid out to workers both under negligence liability and under workers' compensation. In addition, the generosity of benefits varied across states under both the negligence liability and workers' compensation systems. Inspection of employers' liability insurance manuals shows that rates for this insurance were adjusted across the states in order to reflect the different liability rules and the outcomes of litigation in each state. For example, holding the type of industry constant, a firm in Ohio under negligence liability would have paid insurance premiums that were 1.8 times larger than the rates a similar Illinois firm would have paid [DeLeon 1907, pp. 26-27]. These differentials presumably correspond to the different amounts of compensation workers in these two states would have received if they were injured under the negligence liability system. As discussed above and as shown in Table II, the generosity of accident benefits under workers' compensation varied widely across the United States and across time.

To capture this variation in compensation we have calculated an index that corresponds 
better with the generosity of employer-provided accident compensation both before and after workers' compensation. First, we calculated the gross benefits a worker or his family would have received if the worker were killed, suffered a permanent total disability, a permanent partial disability, and a temporary four-week disability. We then converted these gross benefit estimates into an expected benefit measure by weighting each of the four types of accident benefits by the probability of each type of accident occurring and then summing the four expected compensation estimates. The Appendix offers more details on the calculations.

The variable measures the monetary value that a risk-neutral worker would place on his expected accident compensation. If workers were risk-averse, however, our measure of expected compensation actually provides a lower bound estimate of the value that workers would have placed on these post-accident benefits. Further, employers' costs of buying insurance to provide these benefits would have been substantially higher than our estimates of expected benefits. According to the administrative load factors quoted by contemporary insurance texts for workers' compensation insurance (see Kulp, 1928, p. 246), employers would have paid insurance premiums that were about 1.67 times the expected benefit measure we have calculated. ${ }^{15}$

In Table III the second column for each sample presents the weighted least squares results using the expected accident compensation variable as a proxy for the generosity of the two legal regimes governing workplace accident compensation. We estimate the regressions with the real hourly wages as the dependent variable because the coefficient of the expected accident benefits can be easily interpreted. A coefficient of -1 implies that workers fully paid for increases in the expected benefits that they received, although the worker would not have fully paid for the employer's cost of purchasing insurance to provide those benefits. Coefficients of roughly -2.5 would imply that employers were able to pass on their full insurance costs to workers. Using modern data Gruber and Krueger [1991] estimate that workers in the 1970s and 1980s paid for between 56 and 86 percent of their employers' workers' compensation costs. Their results imply that workers more than pay for the value of the expected benefits that they actually receive, but 
do not fully pay for the insurance costs borne by employers. On the other hand, Moore and Viscusi [1990, pp. 50-51] find wage off sets of approximately 3 times the expected value of the worker's accident benefits and 2.4 times employers' insurance costs.

The coefficients of the expected benefits variable in the coal and lumber industries are generally within the range found in modern data. The coal coefficient of -2.29 on expected benefits implies that hourly earnings fell 2.29 cents for each 1 cent increase in the worker's expected accident benefit. Thus, coal workers not only paid for increases in the benefits they expected to receive, but also more than paid for the consequent increase of 2.5 cents in the employers' insurance costs. The offset is smaller in the lumber industry at 1.31 cents for every 1 cent increase in expected compensation. Both the coal and lumber estimates are statistically significantly different from zero. On the other hand, contractual wages in the unionized building trades did not adjust downward to increases in accident compensation. The coefficient is positive (0.413) and not statistically significant.

We have also estimated the various wage equations using a semilog specification often used in wage studies. Table IV gives a summary of the accident benefit coefficients from a variety of different empirical specifications. Column 1 of the table corresponds to the second column for each sample in Table III. Column 2 of Table IV shows the change in the wage associated with a $\$ 1$ increase in expected benefits under the semilog specification, evaluated at the sample mean of average annual earnings for each industry. The estimates based on the semilog specification are similar to the results reported in the level specification. The coal effect is somewhat larger at 3.38. ${ }^{16}$ The lumber tradeoff is somewhat small at -0.85 , and is no longer statistically different from zero. We cannot reject the hypothesis, however, that the lumber coefficient is different from -1 , implying a full wage offset. The building trades effect is again positive and not statistically significant. ${ }^{17}$

These results are generally robust to the inclusion or exclusion of the various labor demand and supply variables in the equations. For example, columns 3 and 4 of Table IV report the wage 
offsets for the level and semilog specifications when only the expected accident compensation variable, along with the dummies for occupations, years, and geography, are included in the estimation. The same patterns are detected. Coal and lumber experience near or greater than dollar for dollar offsets, although the lumber estimates are imprecise. Unionized building tradesmen experienced no of fsets. ${ }^{18}$

The samples cover a period of substantial change in American labor markets. During World War I the federal government played a much larger role in labor and product markets and the war led to substantial shocks to labor and product markets. Nominal wages and the price level rose sharply between 1916 and 1920 and both experienced sharp declines in 1921. Within labor markets the gap between skilled and unskilled wages narrowed and the wages of southern and non-southern workers began to converge. While the year, skill, and location dummy variables help to control for most of these effects, we also try controlling for the effects of these changes by limiting the samples to the period prior to 1916 and reestimating the regressions. The restricted sample still captures the substantial change in post-accident benefits associated with the adoption of workers' compensation, while avoiding the large wage inflation and wage squeeze associated with the U.S. participation in World War I. Comparisons of columns 5 and 6 with columns 1 and 2 in Table IV show that limiting the sample to the early years does not substantially change the results. The coal wage of fet ranges between -1.8 and -2.9 , while the lumber of fet ranges between -0.8 and -1.2 . As before, the contractual wages in the building trades are generally unaffected by the expected benefits variable. These results suggest that the wage of sets that we report for the full samples are not driven by the narrowing of regional or skilled-unskilled wage differentials during World War $\mathbf{I}^{19}$

To further test the robustness of our central results, we limited the sample to states and years when workers' compensation was in effect. This test serves a dual purpose. First, because our estimates of post-accident compensation under negligence liability are less accurate than our measures for workers' compensation, focusing solely on the workers' compensation observations is 
a way to reduce measurement error. ${ }^{20}$ Second, since recent studies using modern data find wage offsets associated with more generous workers' compensation benefits, we would expect to find a similar effect for labor markets in the early twentieth century. We can test the reliability of our data by restricting our attention to the wage adjustment associated with the variations in benefit levels under workers' compensation, ignoring the effect of the big change in expected compensation when the laws were first introduced. As shown in columns 7 and 8 of Table IV, the restricted samples produce the same general patterns found in the full samples. Coal wages in fact show an offset that is substantially larger than the one from the full sample. The lumber offset is precisely estimated in the linear specification, but not in the nonlinear specification. The building trades coefficients are still positive, although larger in magnitude, but not statistically significantly different from zero.

The consistent finding of no wage of fet in the building trades might arise for two reasons. First, it may be that the building trades' success at establishing an official set of contractual wages disguises the full impact of workers' compensation. Changes in post-accident compensation still might have influenced earnings in the building trades through nogotiations of non-scale wages, requirements of greater work intensity, or adjustments in employment. We cannot explore these avenues due to insufficient data.

The second possibility is that unionization enabled workers to fend off wage reductions in the face of increased employer mandates. We might expect such a result from the building trades, which were the most stable labor organizations in the United States in the early 1900s [Taft 1964, p. 203]. Most of the unions' power was focused at the local level, where skilled tradesmen banded together within each occupation. In a number of cities, the unions from various trades organized together in building trades councils that negotiated scales by occupation. The trades councils represented the key skilled workers required for building and the skilled workers controlled access to the training required to obtain their skills. Further, there were low barriers to entry for employers in the building construction fields, so that the trades councils of ten negotiated with a 
large number of competing contractors.

Other studies have shown that workers in unions receive larger compensating differentials for accepting accident risk [Dickens 1984]. Moore and Viscusi [1990, pp. 110-120] find that union workers experience smaller wage of fsets when workers' compensation benefits increase. Dickens [1984] suggests that the union-nonunion variation might arise purely from the differences in the bargaining power of the two sets of workers. Alternatively, Moore and Viscusi [1990] argue that unions obtain better benefits because they represent the preferences of the average worker, while the preferences of the marginal worker determine compensating differentials in competitive markets. Union wages might also be slower to adjust to changes in post-accident compensation because the wages are set in explicit contracts that might be renegotiated every two to three years. Our experiments with lagged (up to three years) expected benefit terms, however, never showed any signs that the building trades experienced a wage offset.

We can further test the impact of unionization on wage offsets by examining the coal sample. In the coal industry the differences in unionization were based on geography, not on occupation, because the philosophy of the United Mine Workers of America (UMWA) was to unionize workers in all jobs into a single union. Our measure of unionization is the percentage of workers in the state with paid up membership in the union. We have reestimated the coal equations from Table III including an interaction term between the union variable and expected benefits. Table $V$ shows the offsets calculated from including the union-expected benefits interaction term both for the overall sample and the sample for the period prior to 1916 . Under the linear specification, the offset for a worker in a completely nonunion district would have been -3.70. Meanwhile, the of fset for a worker in a completely unionized district would have been 0.80 , an effect that is not statistically different from zero. The effect of unionization is sensitive to specification in the full sample, however. The union offset in the semilog specification is slightly larger than the nonunion effect, although the difference between the two is not statistically significant. 
The impact of unionization on wage of fets can be explored further by restricting the sample to the years prior to 1916 . The differences in the results for the two specifications for the full sample might be driven by measurement error in the union variable during and after World War I. The union membership variable might not fully reflect the long-term strength of the union during and immediately after World War I. The U.S. Fuel Administrator had forced many coal firms to negotiate contracts with the union during the War, thus union membership might understate the union's strength in some areas during World War I. After the War ended, a substantial number of firms repudiated the contracts, while union membership was still increasing. To limit the impact of this measurement error in the union variable, we limited the sample to the pre-1916 years. As reported in columns 3 and 4 of Table $V$, under both specifications the union wage of fet is smaller than the nonunion offset.

\section{CONCLUDING REMARKS}

By focusing their attention on the substantial rise in de jure post-accident payments to injured workers, contemporaries hailed workers' compensation legislation as a financial victory for workers and their families. After all labor market adjustments are considered, however, the shift to workers' compensation requires a more complex interpretation. Analysis of the effect of the introduction of workers' compensation on wages shows that in the coal and lumber industries, workers experienced substantial wage offsets. In the coal industry the offsets were large enough to cover not only the expected monetary value of the benefits, but also the employers' costs of purchasing the insurance to provide those benefits. In the lumber industry workers appear to have paid for their expected benefits, but did not fully pay for the employers' cost of purchasing the insurance.

The results for the early 1900 s are quite similar to those presented by Moore and Viscusi [1990] and Gruber and Krueger [1991] for wage of fsets in response to changes in workers' compensation during the 1970 s and 1980 s. Taken as a whole, this body of evidence suggests that 
reforms in modern workers' compensation are not likely to have nearly as large a set of redistributive effects as they might appear by looking at the de jure changes in benefits or cost sharing. Limitations on benefits are likely to be offset by higher wages, and vice versa. Therefore, the focus of policy makers in offering reforms should be on establishing a system that provides workers with the most cost-effective means of insuring their workplace accident risk.

Despite the fact that labor market institutions in the early twentieth century were quite different from today's, the similarity between our findings and those from modern data does not imply that labor market institutions are irrelevant. After all, the contractual wages in the unionized building trades did not show any evidence of a wage of fset. The difference between the building trades and the other two industries may stem from differences in the extent of unionization across the three industries. The building trades were among the most powerful and stable unions at the time. Further analysis of the coal mining results suggest that coal workers in states with greater union membership also experienced smaller wage offsets than nonunion workers. Thus, it appears that unionized workers were able to stave off at least part of the wage offset. This conclusion does not necessarily imply that the introduction of workers' compensation had no offsetting impact on their welfare, however. Adjustments might have been made in noncontractual wages, employment, or in other aspects of the employment relationship.

The presence of wage offsets for nonunion workers also helps to solve one of the major puzzles in the political economy of the passage of workers' compensation. Even though workers' compensation transferred a significant part of the legal burden of post-accident compensation onto employers, many employers led the way in supporting the legislation [Lubove, 1967; Weinstein, 1967]. Many employers may have supported the legislation in anticipation of passing a substantial portion of the costs onto their workers in the form of lower wages.

Politically, workers' attitudes toward workers' compensation may have been influenced by the extent of the wage of fset that they could anticipate. In the final analysis both workers and employers might have benefited from the legislation because the wage of fsets implied that the 
employer-mandate did not create a large-scale redistribution of income. By supporting workers' compensation, employers could satisfy their workers' demands for better post-accident benefits, without having to fully pay for the apparent largesse. Finally, even though their wages might have fallen, risk-averse workers or workers rationed out of the accident insurance market might have benefited from workers' compensation because the laws provided them with an insurance policy against workplace accident risk that was difficult to obtain privately under negligence liability. 


\section{FOOTNOTES}

1. Landes and Posner [1987, pp. 85-87], citing Justice Hand's formula, claim that due care meant that the employer prevented accidents when his costs of prevention were lower than the expected costs of the accidents (i.e., losses to the accident victim times the probability of the accident).

2. See Clark [1908], Weiss [1935], and Epstein [1982] for lucid discussions of the employers' liability system.

3. These figures represent gross compensation and ignore the legal expenses that the victim's family of ten paid. In the 1909-1910 Minnesota study, legal expenses consumed 11.9 percent of the total compensation paid to the families of fatal accident victims. At the higher end of the scale, in $\mathbf{4 6}$ fatal accident cases in Erie County, New York, between 1907 and 1908, the New York State Employers' Liability Commission calculated that 26.3 percent of the gross amount that employers paid to families went to lawyers [Eastman 1910 , p. 290].

The introduction of workers' compensation did not completely eliminate the need for lawyers, however. An injured worker or his family may have had to hire a lawyer if the case was contested. Private insurance companies or self-insuring employers may have contested compensation cases because there was confusion as to whether the accident was caused by a pre-existing condition, about the seriousness of the accident, or what the worker's wage was, which would have determined his compensation. Conyngton [1917, pp. 110-137] found that compensation was contested in 7 of 66 fatal accident cases in Connecticut in 1915 and in 8 of 213 fatal cases in Ohio in 1915. Assuming lawyers collected 25 percent of the families' gross compensation, Conyngton's data suggest that lawyers' fees accounted for between 0.9 and 2.7 percent of the total awards under the new system.

4. Another possible source of accident compensation was employers' subsidies of benefit societies and accident insurance. We do not emphasize this form of compensation very much because the employers' contribution to benefit societies accounted for only a small percentage of the total post-accident compensation received by workers. A large number of benefit societies were either fraternal societies developed by workers or union societies where the employer contributed little or nothing. There were also establishment funds run by the employer, which of ten included no employer subsidies. Eastman [1910, p. 158] found that 23 percent of her sample of workers in Allegheny County, Pennsylvania, were members of benefit societies. Around 1908, most benefit societies paid death benefits in the range of $\$ 100$ to $\$ 300$ (basically the amount needed for a funeral), although a few were more generous. Eastman also found that around 1908, employers generally contributed at most one-third of the funds in the best of relief societies. The one exception was the Carnegie Fund, which was endowed with $\$ 4$ million by Andrew Carnegie and was fully employer-funded. Most relief societies at the establishment level received no contributions from the employer on any regular basis. The U.S. Commissioner of Labor [1909, pp. 448-487] found that in 325 of 461 (70.5 percent) establishment funds, the employer made no regular contribution to the fund.

In determining the extent of employer-funded compensation from the relief societies, say that the societies paid death benefits of $\$ 300$ and each employer contributed one-third of the funds. Since only 23 percent of fatal accident victims were members of relief societies, the maximum average employer contribution to the compensation of a fatal accident victim's family through relief societies was at most \$23, and possibly substantially less. The amount is small enough that it is unlikely to change any of our results 
concerning the wage effects of the shift to workers' compensation. In fact, employers were likely to reduce their share of contributions to relief societies when workers compensation was enacted, making the shift to workers' compensation look even less dramatic than we describe below.

5. The samples referred to in the text were predominately composed of male workers. We did not find risk premiums in the wages paid to women in Indianapolis in 1892 or to children in New Jersey in 1903, possibly because the level and variation of accident risks were smaller for those groups than for men.

6. There were many exceptions to this mandate, however. Most states exempted firms with few workers, such as 5 . In many states, moreover, agriculture, domestic service, casual labor, and public service were excluded from the compensation laws. Sometimes, specific industries were exempted. For example, Maine excluded logging, Maryland exempted country blacksmiths, and Texas excluded cotton ginning. The laws also precluded compensation in cases where the worker was intoxicated at the time he was injured or if he had maliciously caused his own accident. For a more comprehensive summary of the exemptions across the United States, see U.S. Bureau of Labor Statistics [1918, p. 58].

7. Many states enabled families of fatally injured workers to obtain lump sum payments equal to the present value of the stream of payments discounted at statutory rates ranging from 2.5 to 6 percent. The conversion typically required a somewhat paternalistic hearing to determine whether the lump sum was in the best interest of the family. Conyngton [1917, pp. 119-21, 137-44] found that only 8.1 percent of 246 families of fatal accident victims in Ohio in 1915 received lump sums, and another 4.9 percent received their benefits partly as a lump sum and partly as a stream of payments. In Connecticut in 1915, 10.6 percent of the 66 families of fatal accident victims received lump sum payments.

8. The accident probabilities were taken from the Oregon Industrial Accident Commission [1919, pp. 28-42] because the Commission was unique in that it reported the total number of accidents in each accident category and the number of full time workers covered under the workers' compensation system. The calculation further assumes that the hypothetical worker left a widow (aged 30) and two children (aged 8 and 10).

9. We have focused the analysis on $\mathbf{1 3}$ occupational classes from the $\mathbf{4 0}$ specific occupations for which the U.S. Bureau of Labor Statistics reported wage scales by 1923 . The occupations that we have chosen reflect a wide and representative characterization of the important building tasks in the early twentieth-century.

10. All the equations are estimated with weighted least squares because each observation is a state (or city) average from samples of different sizes, which implies that the variance of the error terms is inversely related to the number of workers in each state. In the coal and lumber samples we used the square root of the number of workers sampled for each observation as the weight. In the building sample, where the sample did not give information on number of workers sampled, we used White's [1980] correction for heteroskedasticity.

11. The prices for lumber and coal are the prices at the mill and the mine. Even though both lumber and coal were competitive, national markets, prices at individual mines and mills varied substantially due to differences in the transport costs of sending the product to market and variations in the quality and type of the product. 
12. The full-time hours per week in the lumber and building trades are not measures of labor supply. They reflect the constraints on working time offered by the employer, such that workers might demand higher wages if full-time hours were shortened. Similarly, in the coal industry the days variable is the number of days the tipples operated, representing a measure of the maximum amount of working time available to workers. Workers therefore made their labor-supply decisions subject to the constraints on full-time hours.

13. All calculations are based on the mean earnings in the sample. When the equations are run semilog, the wage reductions in response to workers' compensation are similar, coal at 1.51 percent, lumber at 1.91 percent, and the building trades at 0.35 percent.

14. Insurance companies used experience rating across industries and states to set the workers' compensation premiums. The National Council on Workmen's Compensation, the major interstate ratemaker at the time, typically used the national accident experience in each industry to establish a base accident rate and then adjusted the rates for each state to reflect the generosity of benefits there [Kulp 1928, pp. 235-257]. Some states were large enough that they could use their own accident evidence to experience rate, while insurance companies used national averages to determine premiums in states with smaller populations. Insurance companies and state funds also adjusted premiums for individual firms based on inspections and some experience rating, but the experience rating at this level was less accurate than the comparisons across industries [Kulp 1928, pp. 258-296].

15. We have also tried a specification for the coal sample that interacts the fatal accident rate and expected benefits variable. The wage of fsets are close to the ones reported in the text: -2.04 in the linear specification, and $\mathbf{- 3 . 1 8}$ in the semilog specification. We could not do the same interactions in the lumber and building trades samples because we had no information on differences in accident rates across states and years.

16. We have experimented further by including lagged benefits in the various equations. In every sample when we included a lagged benefits term (up to three years lag) along with the contemporaneous benefits, the coefficient on the lagged term was consistently small and not statistically different from zero.

17. To further investigate whether the dramatic changes in the American labor market during the period under consideration has generated spuriously measured wage of fsets, we collected wage data for a relatively safe industry in an attempt to determine whether these workers experienced a wage of fset, even though they stood to benefit very little from the change in post-accident benefits. If we detected a strong wage offset, then this finding may imply that there is a spurious inverse relationship between benefits and wages during this time period. We investigated a number of the BLS samples, but there was none that had the wide coverage of states that the coal, lumber, and building trades samples have. Cotton textile manufacturing of fered the greatest coverage, but information is available for only 8 states in the early part of the time period under consideration, but it was more like having just two states because the states in the sample were clustered in New England and the southeast. Moreover, the workers' compensation laws in each cluster were very closely related.

Cotton textile work was much less risky than the others considered in this paper. Workers' compensation insurance premiums for cotton mills, for example, were approximately $1 / 10$ of the premiums of coal and 1/5 the premiums for lumber and the building trades (these comparisons are based on the average workers' compensation premiums that employers in each industry would have paid in Ohio, New Jersey, Illinois, and Wisconsin in 1912, as reported in Washington Industrial Insurance Department [1912, 
p. 277]). We estimated regressions for the cotton textile sample with 29 occupations for the years 1910-1914, 1916, 1918, 1920, and 1922. The results revealed a large positive coefficient on the benefits variable, which suggests that we should have fow worries that the time period analyzed here has imparted a spurious negative bias to the relationship between wages and benefits. We are reluctant to draw definitive conclusions from the cotton sample because the small number of states considered sharply limits the effectiveness of our empirical tests.

18. We have investigated the variation further by running separate regressions for each occupation in each industry. As Gruber and Krueger [1991, pp. 128-129] also found, the wage-of fet coefficients for individual occupations vary widely around the estimates from the pooled sample of all occupations. The wage of fsets for each occupation in the coal and lumber industries are typically -1 (or more in absolute value), although some are not precisely estimated. In the building trades, there was a mixture of positive and negative coefficients, but we could detect no consistent pattern of differences in the of fsets for skilled, semiskilled, or unskilled workers.

19. We have tried several methods of calculating benefits under negligence liability, including putting a value of zero in for benefits under negligence liability and assuming benefits based on death benefits of 50 percent of annual earnings, without an adjustment for liability differentials. The results show the same pattern as reported in the text. 


\section{BIBLIOGRAPHY}

Castrovinci, Joseph L., "Prelude to Welfare Capitalism: The Role of Business in the Enactment of Workmen's Compensation Legislation in Illinois, 1905-12, Social Service Review 50 (March 1976), pp. 80-102.

Clark, Lindley D., "The Legal Liability of Employers for Injuries to their Employees, in the United States," U.S. Bureau of Labor Bulletin No. 74 (January 1908).

Clark, Lindley D., and Martin C. Frincke, Jr. "Workmen's Compensation Legislation of the United States and Canada," U.S. Bureau of Labor Statistics Bulletin No. 272 (January 1921).

Conyngton, Mary K., "Effect of Workmen's Compensation Laws in Diminishing the Necessity of Industrial Employment of Women and Children," U.S. Bureau of Labor Statistics, Bulletin No. 217, December 1917.

DeLeon, Edwin W., Manual of Liability Insurance (New York, 1907), pp. 26-27.

Dickens, William T., "Differences Between Risk Premiums in Union and Nonunion Wages and the Case of Occupational Safety Regulation," American Economic Review Papers and Proceedings 74 (1984), pp. 320-323.

Downey, E.H., "Medical Benefits Under Workmen's Compensation," Journal of Political Economy 25 (May, 1917), pp. 580-620.

Eastman, Crystal, Work-Accidents and the Law (New York, 1910).

Epstein, Richard A., "The Historical Origins and Economic Structure of Workers' Compensation Law," Georgia Law Review, 16 (Summer 1982), pp. 775-819.

Fishback, Price V., "Liability Rules and Accident Prevention in the Workplace: Empirical Evidence from the Early Twentieth Century," Journal of Legal Studies, 16 (June 1987), pp. 305-328.

Fishback, Price V., Soft Coal. Hard Choices: The Economic Welfare of Bituminous Coal Miners. 1890 to 1930 (New York: Oxford University Press, 1992).

Fishback, Price V. and Shawn Everett Kantor, "Square Deal' or Raw Deal? Market Compensation for Workplace Disamenities, 1884-1903," Journal of Economic History 52 (December 1992), pp. 826-848

Fisher, Waldo and Anne Bezanson, Wage Rates and Working Time in the Bituminous Coal Industry. 1912-1922 (Philadelphia: University of Pennsylvania Press, 1932).

Fisher, Willard C., "American Experience with Workmen's Compensation," American Economic Review 10 (March 1920), pp. 18-47.

Goldin, Claudia, "Labor Markets in the Twentieth Century," Cambridge Economic History of the United States, edited by Stanley Engerman and Robert Gallman (forthcoming).

Gruber, Jonathan, "The Incidence of Mandated Maternity Benefits," American Economic Review 84 (June 1994), pp. 622-641. 
Gruber, Jonathan and Alan B. Krueger, "The Incidence of Mandated Employer-Provided Insurance: Lessons from Workers' Compensation Insurance," in David Bradford, od., Tax Policy and the Economy (Cambridge, MA, 1991), pp. 111-143.

Hookstadt, Carl, "Comparison of Workmen's Compensation Laws of the United States Up to December 17, 1917," U.S. Bureau of Labor Statistics, Bulletin No. 240 (May 1918).

Hookstadt, Carl, "Comparison of Experience Under Workmen's Compensation and Employers' Liability Systems," Monthly Labor Review 8 (March 1919), pp. 230-248.

Hookstadt, Carl, "Comparison of Workmen's Compensation Laws and Administration, April 1922," U.S. Bureau of Labor Statistics Bulletin No. 301, (Washington, D.C., 1922).

Hookstadt, Carl, "Comparison of Workmen's Compensation Laws of the United States and Canada up to January 1, 1920," U.S. Bureau of Labor Statistics Bulletin No. 275, (Washington, D.C., 1920).

Jones, F. Robertson, Digest of Workmen's Compensation Laws in the United States and Territories, with Annotations, revised to December 1. 1927, (New York: Workmen's Compensation Publicity Bureau, 1927).

Kantor, Shawn Everett and Price V. Fishback, "Coalition Formation and the Adoption of Workers' Compensation: The Case of Missouri, 1911 to 1926," in Claudia Goldin and Gary D. Libecap, eds., The Regulated Economr: A Historical Aoproach to Political Economy (Chicago: University of Chicago Press and NBER, 1994).

Kantor, Shawn Everett and Price V. Fishback, "Non-Fatal Accident Compensation and the Common Law at the Turn of the Century," University of Arizona Department of Economics Working Paper, 1993.

Kim, Seung-Wook and Price V. Fishback, "Institutional Change, Compensating Differentials, and Accident Risk in Railroading, 1892-1945," Journal of Economic History 53 (December 1993), pp. 796-823.

Kulp, C.A., Casualty Insurance (New York, 1928).

Landes, William M. and Posner, Richard A., The Economic Structure of Tort Law (Cambridge, MA, 1987).

Lubove, Roy, "Workmen's Compensation and the Prerogatives of Voluntarism," Labor History 8 (Fall 1967): 254-279.

Minnesota Bureau of Labor, Industries and Commerce, Twelfth Annual Report. 1909-1910.

Moore, Michael J. and W. Kip Viscusi, Compensation Mechanisms for Job Risks: Wages. Workers' Compensation, and Product Liability (Princeton, NJ, 1990).

National Industrial Conference Board, The Workmen's Compensation Problem in New York State (New York, 1927), pp. 311-313.

Oregon Industrial Accident Commission, Second Report for the Two Year Period Ending June 30. 1917 (Salem, OR, 1919). 
Posner, Richard A., "A Theory of Negligence," Iournal of Leral Studies, 1 (Jan. 1972), pp. 29-96.

Riggleman, John Randolph, Yariations in Building Activity in United States Cities (Ph.D. dissertation, Johns Hopkins University, 1934).

Taft, Philip, Organized Labor in American History (New York: Harper and Row, 1964).

U.S. Bureau of the Census, Historical Statistics of the United States. Colonial Times to 1970 (Washington: GPO, 1975)

U.S. Bureau of Labor Statistics, "Workmen's Compensation Laws of the United States and Foreign Countries, December 23, 1913, Bulletin No.126 (Washington: Govt. Pr. Off., 1914).

U.S. Bureau of Labor Statistics, "Workmen's Compensation Laws of the United States and Foreign Countries," U.S. Bureau of Labor Statistics Bulletin.No. 203 (January 1917).

U.S. Bureau of Labor Statistics, "Workmen's Compensation Legislation in the United States and Foreign Countries, 1917 and 1918," U.S. Bureau of Labor Statistics Bulletin No. 243 (Washington, 1918).

U.S. Bureau of Labor Statistics, "Workmen's Compensation Legislation of the United States and Canada, 1920 to 1922," U.S. Bureau of Labor Statistics Bulletin No. 332 (Washington, June 1923).

U.S. Bureau of Labor Statistics, "Workmen's Compensation Legislation of the United States and Canada as of July 1, 1926," U.S. Bureau of Labor Statistics Bulletin No. 423 (Washington, 1926).

U.S. Commissioner of Labor, Workmen's Insurance and Benefit Funds in the United States (Washington, 1909).

Washington Industrial Insurance Department, First Annual Report for the Twelve Monthe Ending September 30th 1912 (Olympia, WA, 1912).

Weinstein, James, "Big Business and the Origins of Workmen's Compensation," Labor History 8 (Spring 1967), pp. 156-174.

Weiss, Harry, "Employers' Liability and Workmen's Compensation," in John R. Commons, ed., History of Labor in the United States, 1896-1932 (New York, 1935).

White, Halbert, "A Heteroskedasticity-Consistent Covariance Matrix Estimation and a Direct Test for Heteroskedasticity," Econometrica, 48 (May 1980), pp. 817-838.

Wisconsin Industrial Commission, Annual Report (Madison, WI, 1915, 1916, 1917). 
TABLE I

De Facto Compensation Paid to Families of Fatal

Industrial Accident Victims Under Negligence Liability

\begin{tabular}{|c|c|c|c|}
\hline Sample & $\begin{array}{l}\text { Number of Useable } \\
\text { Observation: }\end{array}$ & $\begin{array}{l}\text { Percentage } \\
\text { Receiving No } \\
\text { Compensation from } \\
\text { Employers }\end{array}$ & $\begin{array}{l}\text { Mean Ratio of } \\
\text { Compensation to } \\
\text { Annual Earnings }\end{array}$ \\
\hline $\begin{array}{l}\text { Married Non-Railroad Workers in } \\
\text { Erie County, NY, 1907-08 }\end{array}$ & 60 & 35.0 & 0.69 \\
\hline $\begin{array}{l}\text { Married Workers in Manhattan, } \\
\text { NY, before } 1910^{2}\end{array}$ & 48 & 37.5 & 0.78 \\
\hline $\begin{array}{l}\text { New York State Employers' } \\
\text { Liability Commission Report on } \\
\text { Married Workers Before } 1910\end{array}$ & 111 & -- & 0.56 \\
\hline $\begin{array}{l}\text { All Married Workers Killed in } \\
\text { Work Accidents in Allegheny } \\
\text { County, PA, } 7 / 1 / 06 \text { to } 6 / 30 / 07^{b}\end{array}$ & 225 & 30.2 & 0.44 \\
\hline $\begin{array}{l}\text { Workers in Virginia Coal Mines } \\
\text { Owned by Stonega Coke and Coal, } \\
\text { 1916-1918 }\end{array}$ & 44 & 29.4 & 0.41 \\
\hline $\begin{array}{l}\text { Married Workers in Pennsylvania, } \\
1915\end{array}$ & 116 & 45.6 & 0.38 \\
\hline $\begin{array}{l}\text { Non-Railroad Workers in } \\
\text { Minnesota, 1909-1910 }\end{array}$ & 45 & 22.2 & 1.12 \\
\hline $\begin{array}{l}\text { Non-Railroad Workers in Illinois } \\
\text { before } 1911\end{array}$ & 274 & 60.9 & 0.58 \\
\hline Weighted (by sample size) Average & & 43.1 & 0.56 \\
\hline
\end{tabular}


TABLE I (continued)

Notes: All of the workers represented in the samples were men. In each sample there are several cases where the payments are unknown. Most of the unknown cases are situations in which lawsuits were pending. Hookstadt and some other authors treat the pending suits as receiving no compensation when calculating the average payment to all accident victims. In the calculations above, however, we have treated the unknowns as missing values. The information for Pennsylvania workers in 1915 actually understates the extent of compensation because there are several cases treated as unknown where the employers' payments were too complex to easily attach a dollar figure. In 9 cases the employer gave the use of a house to the family and in 21 cases listing no payment and one listing $\mathbf{5 5}$, the families had engaged counsel to settle or bring suit (in a number of these cases the families had actually refused settlement offers ranging from $\$ 50$ to $\$ 3000$ ). In one case in Minnesota we included only the $\$ 1000$ received by the worker from his employer; he also received \$5,352 from an Electric Light Company that was not his employer.

- The evidence on compensation was presented as frequency distributions across ranges of dollar amounts. The midpoint of each range was used to calculate the mean levels of compensation.

b The sample includes workers employed by Carnegie Steel who received compensation from the Carnegie Fund, which was a relief fund solely funded by the employer. It seems reasonable to include this because the Fund may have reduced the number of suits filed against the Carnegie Company and also was fully funded by the employer. There may be some other payments from other relief funds that were partially funded by employers, so the compensation may be overstated. Eastman is not clear about whether these are included or excluded.

Sources: The estimates from New York and Allegheny County, Pennsylvania, are from Eastman [1910, pp. 122, 272-279]. Virginia coal mine estimates are from Fishback [1987, pp. 311-312]. The Pennsylvania data for 1915 are from Conyngton [1917, pp. 125-145]. The Minnesota information comes from the Minnesota Bureau of Labor, Industries and Commerce [1909-1910, pp. 166-169]. The Illinois data are from Hookstadt [1919, p. 239]. In calculating the ratio of expected compensation to yearly earnings, we used the workers' reported wages for the three New York samples, and the Allegheny County, PA, and Pennsylvania samples. Average yearly earnings for the other samples are from Paul Douglas's estimates of annual earnings in U.S. Bureau of the Census [1975, p. 168]. The average for coal miners is that from bituminous coal mining and the average for non-railroad workers is that for manufacturing wage earners in all industries. 
TABLE II

\section{Expected Benefits Under Workers' Compensation \\ As a Percentage of Annual Earnings by State, 1910-1923}

\begin{tabular}{|c|c|c|c|c|c|c|c|c|c|c|c|c|c|c|}
\hline $\begin{array}{l}\text { State } \\
\text { AK } \\
\text { AL }\end{array}$ & $\begin{array}{l}1910 \\
\cdot \\
\cdot\end{array}$ & $\begin{array}{l}1911 \\
\cdot \\
\cdot\end{array}$ & $\begin{array}{l}1912 \\
\cdot \\
\cdot\end{array}$ & $\begin{array}{l}1913 \\
\cdot \\
.\end{array}$ & $\begin{array}{l}1914 \\
. \\
.\end{array}$ & $\begin{array}{l}1915 \\
2.02 \\
\cdot\end{array}$ & $\begin{array}{l}1916 \\
1.85 \\
.\end{array}$ & $\begin{array}{l}1917 \\
1.67 \\
.\end{array}$ & $\begin{array}{l}1918 \\
1.44 \\
.\end{array}$ & $\begin{array}{l}1919 \\
1.30 \\
\cdot\end{array}$ & $\begin{array}{l}1920 \\
1.12 \\
0.98\end{array}$ & $\begin{array}{l}1921 \\
1.20 \\
1.07\end{array}$ & $\begin{array}{l}1922 \\
1.24 \\
1.13\end{array}$ & $\begin{array}{l}1923 \\
1.54 \\
1.05\end{array}$ \\
\hline AR & . & . & . & & & & & . & & . & & & & \\
\hline $\mathrm{AZ}$ & . & . & $\therefore$ & 1.36 & 1.36 & 1.36 & 1.35 & 1.32 & 1.22 & 1.15 & 1.04 & 1.98 & 2.04 & 1.93 \\
\hline $\mathrm{CA}$ & . & 1.57 & 1.57 & 1.60 & 1.41 & 1.41 & 1.43 & 1.43 & 1.51 & 1.57 & 1.47 & 1.54 & 1.55 & 1.54 \\
\hline $\mathrm{CO}$ & - & $\cdot$ & $\cdot$ & $\cdot$ & & 0.88 & 0.80 & 0.80 & 0.66 & 0.77 & 0.63 & 0.69 & 0.72 & 0.84 \\
\hline CT & . & . & . & $\cdot$ & 1.11 & 1.17 & 1.17 & 1.17 & 1.16 & 1.32 & 1.22 & 1.27 & 1.30 & 1.26 \\
\hline DE & . & . & . & . & $\cdot$ & $\cdot$ & $\cdot$ & $\cdot$ & 0.91 & 1.24 & 1.11 & 1.22 & 1.25 & 1.19 \\
\hline FL & . & - & - & - & - & • & - & . & . & • & . & & & \\
\hline GA & - & - & - & - & - & : & . & . & . & . & . & 0.78 & 1.12 & 1.08 \\
\hline HI & - & - & - & - & - & 1.30 & 1.30 & 1.43 & 1.43 & 1.37 & 1.25 & 1.35 & 1.38 & 1.35 \\
\hline ID & - & - & . & . & . & & & & 1.29 & 1.12 & 0.92 & 1.30 & 1.36 & 1.27 \\
\hline IL & . & . & 1.31 & 1.30 & 1.30 & 1.30 & 1.29 & 1.42 & 1.33 & 1.31 & 1.07 & 1.21 & 1.27 & 1.18 \\
\hline IN & - & • & - & • & & 1.19 & 1.19 & 1.31 & 1.31 & 1.21 & 0.99 & 1.08 & 1.13 & 1.05 \\
\hline IA & - & • & : & : & 1.08 & 1.08 & 1.08 & 1.08 & 0.90 & 1.16 & 0.95 & 1.04 & 1.09 & 1.02 \\
\hline KS & - & • & 1.10 & 1.10 & 1.10 & 1.10 & 1.10 & 1.34 & 1.34 & 1.19 & 0.98 & 1.07 & 1.12 & 1.04 \\
\hline KY & - & • & • & • & $\cdot$ & & 1.44 & 1.34 & 1.22 & 1.06 & 1.00 & 1.09 & 1.15 & 1.07 \\
\hline LA & - & • & $\therefore$ & $\therefore$ & $\therefore$ & 1.08 & 1.20 & 1.19 & 1.31 & 1.31 & 1.26 & 1.34 & 1.43 & 1.36 \\
\hline MA & - & • & 1.37 & 1.36 & 1.83 & 1.84 & 1.76 & 1.72 & 1.48 & 1.37 & 1.14 & 1.24 & 1.45 & 1.41 \\
\hline MD & - & • & 1.03 & 1.03 & 1.19 & 1.19 & 1.19 & 1.19 & 1.13 & 1.00 & 1.33 & 1.46 & 1.53 & 1.42 \\
\hline ME & • & . & & . & & & 1.14 & 1.14 & 0.97 & 1.23 & 1.03 & 1.28 & 1.33 & 1.25 \\
\hline MI & - & · & 1.06 & 1.06 & 1.06 & 1.06 & 1.06 & 1.06 & 0.88 & 1.19 & 0.97 & 1.09 & 1.15 & 1.06 \\
\hline MN & $\cdot$ & • & • & 1.08 & 1.08 & 1.13 & 1.13 & 1.38 & 1.15 & 1.29 & 1.05 & 1.45 & 1.51 & 1.63 \\
\hline MO & $\cdot$ & $\cdot$ & • & • & • & - & - & - & - & • & - & - & - & - \\
\hline MS & • & $\cdot$ & • & - & - & & & - & & 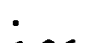 & & & & \\
\hline MT & • & • & • & • & • & 1.18 & 1.18 & 1.17 & 0.98 & 1.06 & 0.87 & 0.96 & 1.00 & 0.93 \\
\hline MC & • & $\cdot$ & $\cdot$ & • & - & - & $\cdot$ & - & - & . & - & & & \\
\hline ND & $\cdot$ & $\cdot$ & • & & & & & & & 2.26 & 2.04 & 2.21 & 2.26 & 2.16 \\
\hline NE & • & - & - & 1.17 & 1.17 & 1.17 & 1.17 & 1.55 & 1.28 & 1.39 & 1.14 & 1.25 & 1.31 & 1.22 \\
\hline NH & • & & 1.18 & 1.18 & 1.18 & 1.18 & 1.18 & 1.18 & 1.02 & 0.91 & 0.79 & 0.84 & 0.87 & 1.17 \\
\hline NJ & • & 1.06 & 1.06 & 1.06 & 1.06 & 1.06 & 1.06 & 1.05 & 0.91 & 1.01 & 0.82 & 0.91 & 0.95 & 1.18 \\
\hline NM & - & $\cdot$ & . & & & : & : & 0.91 & 0.83 & 0.95 & 0.81 & 0.94 & 0.98 & 0.92 \\
\hline NV & & & & 1.28 & 1.39 & 1.51 & 1.50 & 1.50 & 1.74 & 2.02 & 1.70 & 1.84 & 1.92 & 1.80 \\
\hline NY & 1.67 & 1.67 & 1.65 & 1.74 & 1.84 & 1.84 & 1.84 & 1.83 & 1.78 & 1.65 & 1.43 & 1.55 & 1.83 & 1.79 \\
\hline $\mathrm{OH}$ & • & • & 1.47 & 1.59 & 1.65 & 1.65 & 1.65 & 1.50 & 1.39 & 1.30 & 1.06 & 1.22 & 1.28 & 1.19 \\
\hline OK & $\cdot$ & - & • & $\cdot$ & & 0.69 & 0.69 & 0.69 & 0.57 & 0.92 & 0.9 & 0.92 & 0.92 & 0.95 \\
\hline OR & . & • & . & - & 1.77 & 1.77 & 1.66 & 1.49 & 1.23 & 1.1 & 0.9 & 1.27 & 1.29 & 1.25 \\
\hline PA & • & • & - & - & & : & 1.12 & 1.12 & 0.93 & 0.81 & 0.7 & 0.86 & 0.90 & 0.84 \\
\hline II & • & • & 1.14 & 1.14 & 1.14 & 1.14 & 1.14 & 1.37 & 1.18 & 1.05 & 1.04 & 1.18 & 1.20 & 1.17 \\
\hline C & - & - & • & • & - & • & - & & & & & & & \\
\hline SD & • & • & - & • & - & - & - & 1.08 & 1.02 & 0.9 & 0.7 & 1.0 & 1.0 & 0.98 \\
\hline TN & - & - & • & & & & & & & 0.94 & 0.77 & 0.84 & 0.8 & 1.08 \\
\hline TX & $\cdot$ & - & - & 1.66 & 1.66 & 1.66 & 1.64 & 1.48 & 1.48 & 1.34 & 1.10 & 1.20 & 1.26 & 1.48 \\
\hline UT & . & . & - & - & • & & - & 1.28 & 1.21 & 1.47 & 1.20 & 1.32 & 1.38 & 1.29 \\
\hline $\begin{array}{r}V A \\
V T\end{array}$ & . & - & . & - & - & & & & & 0.78 & 0.76 & 0.84 & 0.88 & 0.82 \\
\hline VT & & • & ${ }^{\circ}$ & • & & 0.96 & 0.95 & 0.95 & 1.03 & 0.95 & 0.87 & 1.05 & 1.07 & 1.03 \\
\hline
\end{tabular}




$\begin{array}{lllllllllllllll}\text { WA } & \cdot & 1.73 & 1.67 & 1.62 & 1.62 & 1.62 & 1.46 & 1.38 & 1.14 & 1.43 & 1.17 & 1.28 & 1.35 & 1.40 \\ \text { WI } & \cdot & 1.73 & 1.68 & 1.45 & 1.45 & 1.45 & 1.32 & 1.45 & 1.21 & 1.06 & 0.88 & 1.60 & 1.67 & 1.58 \\ \text { WV } & \cdot & \cdot & \cdot & 1.31 & 1.31 & 1.30 & 1.21 & 1.12 & 0.93 & 1.12 & 0.91 & 1.00 & 1.05 & 1.32 \\ \text { WY } & \cdot & \cdot & \cdot & \cdot & . & 1.04 & 0.93 & 1.03 & 0.85 & 0.96 & 0.93 & 1.22 & 1.27 & 1.18\end{array}$

Notes: A period implies that no workers' compensation law was in effect during that year. Some states enacted the laws in the year prior to its going into effect. The expected benefits are as of the end of the year. Maryland in 1910 had a set of benefits for coal miners in Garrett and Alleghany Counties, which were not as lucrative as the ones they introduced in 1914. Montana also experimented with workers' compensation earlier, but the law was declared unconstitutional. Kentucky in 1914 passed a law that was declared unconstitutional before it could go into effect. New York's law in 1910 reflects the elective law. A compulsory law for more dangerous industries was enacted in 1910 , but it was declared unconstitutional.

Sources: Using the national average manufacturing weekly wage, we calculated expected benefits following the procedures described in the Appendix. We then divided the expected benefits by annual earnings ( 52 times the weekly wage) and multiplied by 100 . We derived the weekly wage by multiplying weekly hours (series D765, p. 168 ) and hourly earnings (series D766, p. 168) for the period 1900 to 1926 [U.S. Census Bureau, 1975, p. 168]. 
TABLE III

Fixed-Effects Weighted Least Squares Wage Regressions (dependent variable is hourly wage in 1890-1899 dollars)

\begin{tabular}{|c|c|c|c|c|c|c|}
\hline Variable & $\begin{array}{l}\text { Coal Mini } \\
\text { Wage Wor }\end{array}$ & $\begin{array}{l}\text { Hourly } \\
\text { rs }\end{array}$ & Lumber $M$ & Workers & $\begin{array}{l}\text { Unlonized } \\
\text { Trades }\end{array}$ & Bullding \\
\hline Worker's Compensation Dummy & $\begin{array}{l}-0.006 \\
(3.76)\end{array}$ & & $\begin{array}{l}-0.0033 \\
(2.613)\end{array}$ & & $\begin{array}{l}-0.0012 \\
(0.614)\end{array}$ & \\
\hline $\begin{array}{l}\text { Expected Present Value of } \\
\text { Accident Compensation }\end{array}$ & & $\begin{array}{l}-2.23 \\
(4.43)\end{array}$ & & $\begin{array}{l}-1.306 \\
(2.287)\end{array}$ & & $\begin{array}{l}0.413 \\
(1.125)\end{array}$ \\
\hline Limits on Working Time & $\begin{array}{l}0.000005 \\
(0.138)\end{array}$ & $\begin{array}{l}0.00003 \\
(0.74)\end{array}$ & $\begin{array}{l}-0.0036 \\
(18.947)\end{array}$ & $\begin{array}{l}-0.0036 \\
(18.613)\end{array}$ & $\begin{array}{l}-0.0248 \\
(22.548)\end{array}$ & $\begin{array}{l}-0.0084 \\
(22.776)\end{array}$ \\
\hline $\begin{array}{l}\text { Product Price or Other Product } \\
\text { Demand Index }\end{array}$ & $\begin{array}{l}0.0846 \\
(17.67)\end{array}$ & $\begin{array}{l}0.0835 \\
(17.59)\end{array}$ & $\begin{array}{l}0.00277 \\
(6.756)\end{array}$ & $\begin{array}{l}0.00283 \\
(6.902)\end{array}$ & $\begin{array}{l}0.00079 \\
(3.591)\end{array}$ & $\begin{array}{l}0.00043 \\
(4.943)\end{array}$ \\
\hline Productivity Measure & $\begin{array}{l}0.0643 \\
(3.46)\end{array}$ & $\begin{array}{l}0.0755 \\
(4.06)\end{array}$ & $\begin{array}{l}0.00004 \\
(2.440)\end{array}$ & $\begin{array}{l}0.00004 \\
(2.421)\end{array}$ & & \\
\hline Fatal Accident Rate & $\begin{array}{l}-0.00029 \\
(0.51)\end{array}$ & $\begin{array}{l}-0.00008 \\
(0.14)\end{array}$ & & & & \\
\hline $\begin{array}{l}\text { Paid-Up Membership in the } \\
\text { United Mine Workers as a } \\
\text { Percentage of Employment }\end{array}$ & $\begin{array}{l}0.0011 \\
(0.16)\end{array}$ & $\begin{array}{l}0.0025 \\
(0.37)\end{array}$ & & & & \\
\hline Strike Days per Employee & $\begin{array}{l}0.0001 \\
(2.56)\end{array}$ & $\begin{array}{l}0.00012 \\
(3.18)\end{array}$ & & & & \\
\hline $\begin{array}{l}\text { Strike Days per Employee Lagged } \\
\text { One Year }\end{array}$ & $\begin{array}{l}-0.00006 \\
(2.28)\end{array}$ & $\begin{array}{l}-0.00005 \\
(2.24)\end{array}$ & & & & \\
\hline $\begin{array}{l}\text { Strike Days per Employee in Rest } \\
\text { of Coal Industry }\end{array}$ & $\begin{array}{l}0.00072 \\
(4.00)\end{array}$ & $\begin{array}{l}0.00075 \\
(4.39)\end{array}$ & & & & \\
\hline Intercept & $\begin{array}{l}0.035 \\
(2.52)\end{array}$ & $\begin{array}{l}0.0254 \\
(1.89)\end{array}$ & $\begin{array}{l}-0.0033 \\
(2.62)\end{array}$ & $\begin{array}{l}0.173 \\
(23.46)\end{array}$ & $\begin{array}{l}0.771 \\
(45.69)\end{array}$ & $\begin{array}{l}0.413 \\
(1.125)\end{array}$ \\
\hline Occupation Dummies & 9 of 10 & 9 of 10 & 9 of 10 & 9 of 10 & 12 of 13 & 12 of 13 \\
\hline Geography Dummies & $\begin{array}{l}22 \text { of } 23 \\
\text { states }\end{array}$ & $\begin{array}{l}22 \text { of } 23 \\
\text { states }\end{array}$ & $\begin{array}{l}22 \text { of } 23 \\
\text { states }\end{array}$ & $\begin{array}{l}22 \text { of } 23 \\
\text { states }\end{array}$ & $\begin{array}{l}76 \text { of } 77 \\
\text { cities }\end{array}$ & $\begin{array}{l}76 \text { of } 77 \\
\text { cities }\end{array}$ \\
\hline Year Dummies & included & included & included & included & included & included \\
\hline $\mathbf{N}$ & 2690 & 2690 & 1236 & 1236 & 6563 & 6563 \\
\hline
\end{tabular}


Notes: Absolute value of t-statistics in parentheses below coefficient estimates. Coefficients of the occupation, year, and geography dummies are available from the authors. F-tests reject the hypothesis that the coefficients of these dummy variables are simultaneously zero. The mean of the wage is 0.2769 (standard deviation of 0.28 ) in the coal sample; 0.204 $(0.104)$ in the lumber sample; and $0.373(0.094)$ in the building trades sample. Since the information is based on means from states with different sample sizes, heteroskedasticity with the variance of the error term related to the inverse of the sample size is expected. Glejser tests confirmed the presence of this type of heteroskedasticity. We therefore used weighted least squares. In the coal estimation the square root of the number of coal workers in the state was used as the weight. In the lumber sample, the square root of the number of sampled workers is used as the weight. The building trades data did not report sample size, so White's [1980] method is used to adjust the standard errors.

Sources: Average hourly earnings in the coal industry are from Fisher and Bezanson [1932, pp. 254-289, 296-325]. In states where there were multiple districts, we aggregated the wages across districts up to the state level using the amount of coal produced [Fisher and Bezanson, pp. 338-349] to calculate the weighted average. The deflator for dollar amounts is Paul Douglas's cost-of-living index (1890-1899=100), series E185 in U.S. Bureau of Commerce [1975, p. 212]. The union variable was reported in U.S. Coal Commission, Report. Part III (Washington: GPO, 1925), p. 1052, with straight-line interpolations to fill years not reported. Data for the remaining variables were compiled from U.S. Bureau of Mines Bulletins titled, "Coal-Mine Fatalities in the year ...," and U.S. Geological Survey (after 1922 Bureau of Mines) publications titled, Mineral Resources of the United States. Part II. Nonmetalk, various years. For more details on the sample, see Appendix B of Fishback [1992, pp. 234-241].

The lumber data set includes 23 states for the years 1910-1913, 1915, 1921, and 1923. Wage and hours worked data for each of the lumber occupations were collected from the following U.S. Bureau of Labor Statistics Bulletins: "Wages and Hours of Labor in the Lumber, Millwork, and Furniture Industries, 1890-1912," Bulletin No. 129 (Washington, 1913); "Wages and Hours of Labor in the Lumber, Millwork, and Furniture Industries, 1907-1913," Bulletin No. 153 (Washington, 1914); "Wages and Hours of Labor in the Lumber, Millwork, and Furniture Industries, 1915," Bulletin No. 225 (Washington, 1918); "Wages and Hours of Labor in the Lumber, Millwork, and Furniture Industries, 1921," Bulletin No. 317 (Washington, 1923); "Wages and Hours of Labor in the Lumber, Millwork, and Furniture Industries, 1923," Bulletin No. 363 (Washington, 1924). The lumber price index is a weighted (by output) mean of the prices for individual species of lumber. Price and output data are reported in U.S. Department of Agriculture, "Lumber Productions in the United States, 1799-1946," Miscellaneous Publication No. 669 (Washington, 1948).

The building trades data set includes 77 cities (or city pairs), encompassing 35 states. The data set includes the years 1907 to 1923, inclusive. Wage and hours worked data for each of the building occupations were collected from the following U.S. Bureau of Labor Statistics "Union Scale of Wages and Hours of Labor" Bulletins (year(s) of coverage in parentheses): No. 131 (19071912); No. 143 (1913); No. 171 (1914); No. 194 (1915); No. 214 (1916); No. 245 (1917); No. 259 (1918); No. 274 (1919); No. 286 (1920); No. 302 (1921); No. 325 (1922); and No. 354 (1923). The per capita value of building permits data were collected from Riggleman [1934, pp. 263-276]. The building permit data were reported at the regional level, so we matched each city observation to its particular region for the given year. 
TABLE IV

Wage Offsets Associated with Different Specifications

(-1 implies dollar-for-dollar wage offset for $\mathbf{\$} 1$ increase in expected accident compenation)

\begin{tabular}{llllllllll} 
Specification & All Years & \multicolumn{3}{c}{$\begin{array}{l}\text { Only Compensation } \\
\text { and Dummiles } \\
\text { Included }\end{array}$} & Prior to 1916 & \multicolumn{3}{c}{$\begin{array}{l}\text { Only Workers' } \\
\text { Compensation States } \\
\text { and Years }\end{array}$} \\
Sample & Linear & Semilog & Linear & Semillog & Linear & Semilog & Linear & Semilog \\
Coal & -2.23 & -3.38 & -2.22 & -3.53 & -1.87 & -2.89 & -2.83 & -4.70 \\
& $(4.43)$ & $(5.60)$ & $(4.15)$ & $(5.43)$ & $(3.40)$ & $(3.72)$ & $(2.61)$ & $(3.80)$ \\
Lumber & -1.31 & -0.82 & -0.98 & -0.66 & -1.16 & -0.82 & -2.45 & -0.77 \\
& $(2.29)$ & $(1.22)$ & $(1.51)$ & $(0.80)$ & $(1.98)$ & $(1.46)$ & $(1.86)$ & $(0.53)$ \\
Unionized Building & 0.41 & 0.43 & 0.27 & $\mathbf{0 . 2 4}$ & $\mathbf{0 . 1 8}$ & $\mathbf{- 0 . 1 5}$ & 2.27 & 1.95 \\
Trades & $(1.13)$ & $(1.22)$ & $(0.68)$ & $(0.63)$ & $(0.44)$ & $(0.38)$ & $(2.57)$ & $(3.18)$
\end{tabular}

Notes: Absolute value of $\mathrm{t}$-statistics in parentheses.

Sources: The entries for the linear specifications are the actual coefficient from the regression. The entry for the semilog specification is evaluated at the mean wage rate for each sample. Each regression contained the variables listed in Table III, although the list of year and state dummies was adjusted to include only years and states included in the samples. The coefficients and t-statistics of the variables not reported here are available from the authors. 


\section{TABLE V}

\section{Union and Nonunion Wage Offets in the Coal Industry ( -1 implies dollar-for-dollar wage offset for $\$ 1$ increase in expected accident compensation)}

\begin{tabular}{llllll} 
& \multicolumn{2}{c}{ Full Sample } & \multicolumn{2}{c}{ Prior to 1916} \\
Sample & Linear & Semilog & Linear & Semilog \\
Coal Nonunion & -3.70 & -3.15 & -3.70 & -3.83 \\
& $(5.66)$ & $(4.06)$ & $(4.47)$ & $(3.28)$ \\
Coal Union & -0.80 & -3.53 & -0.52 & -2.18 \\
& $(1.24)$ & $(4.60)$ & $(0.72)$ & $(0.59)$
\end{tabular}

Notes: Absolute value of $\mathbf{t}$-statistics in parentheses.

Sources: See Table III. The entry for the linear specification is the actual coefficient from the regression. The nonunion entry is based on the coefficient on the expected benefits term, while the union entry is determine by summing the coefficients of the expected benefit variable and the union-expected-benefits interaction term. The entry for the semilog specification is evaluated at the sample mean wage rate for each sample. Each regression contained the variables listed in Table III. The coefficients and t-statistics of the variables not reported here are available from the authors. 
Appendix

\section{Constructing the Expected Benefit Variable}

The expected benefit measure used in the wage regressions is essentially the probability of an accident multiplied by the present value of the stream of benefits paid to the worker if he were to experience an industrial accident. The calculation is more complicated because the worker could suffer a variety of accidents, each with a different probability and payout scheme.

Workers' compensation commissions typically classified accidents into four broad categories: fatal, permanent total disability, permanent partial disability, and temporary disability. Permanent total disability accidents were relatively rare and the payments were very close to the fatal accident payouts, so we merged the permanent total disability and fatal accident categories together. Using the national average weekly wage for each occupation in each sample (see below for further discussion of this choice), we then calculated the benefits that would have been paid for a typical accident in each category. For the permanent partial disability category, we used the loss of a hand as a typical accident because the payment structure for the amputation of a hand was described in every law in every state. The typical accident in the permanent partial category, however, was actually much less serious. Based on actual accident statistics reported by the Wisconsin Industrial Commission [1915, p. 41; 1916, p. 44; 1917, pp. 6-7] for 1914 to 1917 , we found that the average payments for permanent partial disabilities was 21.9 percent of that for the loss of a hand. Thus, in computing our payment for a permanent partial accident, we scaled down the payout for the hand by multiplying the figure by 21.9 percent. We treated the typical temporary disability accident as putting workers out of work for 5 weeks. We then took the typical benefit in each category, multiplied by the per hour probability of an accident occurring in that category, and then summed across categories.

When calculating benefits in each category we took the statutory descriptions of the payments for accidents to a married worker with two children as the basis for our workers' compensation payment. We assumed the children were ages 8 and 10 and that the deceased's widow did not remarry and lived another 30 years. We obtained the statutory descriptions from various Bulletins of the United States Bureau of Labor Statistics in the Workmen's Compensation and Insurance Series [U.S. Bureau of Labor Statistics, 1914, 1917, 1918, 1923, and 1926; Hookstadt, 1920 and 1922; and Clark and Frincke, 1921] We also used Jones [1927]. When we needed to settle questions about the timing of changes in the law, the state's statutes were consulted directly.

For fatal accidents, the typical law allowed weekly payments to be a percentage (up to $2 / 3$ ) of the weekly wage for a specified period of time. We calculated the present value (using continuous discounting) of the stream of benefits using a discount rate of 10 percent. We chose 10 percent because we are looking at benefits from the workers' perspective. The calculations were sometimes complicated because states usually imposed maximums on the weekly payout or maximum total payouts. If the percentage times the weekly wage exceeded the maximum weekly payment, we inserted the maximum weekly payment into the present value calculations. In cases where there was a maximum total payment, we assumed the family received the regular weekly payment until the total undiscounted stream of payments reached the maximum total. Thus we determined the number of weekly payments by taking the maximum total divided by the weekly payment (states did not worry about discounting issues when deciding when a family reached its maximum total benefit).

For the loss of a hand, the typical state paid a percentage of the weekly wage for a fixed amount of time, subject to minimum and maximum weekly amounts. Some states commenced the hand payments after the worker collected a statutory amount of temporary disability pay.

Following the recommendations of the International Association of Industrial Accident Boards and Commissions in 1920 (Hookstadt, 1920, p. 77), we assumed that the loss of a hand temporarily disabled the worker fully for 15 weeks before he could return to work. We calculated the present 
value of the stream of payments using continuous discounting. It was important to calculate the present value because some states would pay a relatively small amount per week for the rest of the worker's life. Without discounting the total amount paid would look quite large when in fact, the present value of the stream of payments was in the range seen for other states. In the few cases where a hand payment was not mentioned specifically, we followed the BLS in describing it as a 50 percent disability.

For temporary disabilities workers were paid a percentage of their weekly wage during the period of the disability, which we assumed to be 5 weeks. These payments were usually subject to minimum and maximum weekly amounts. Nearly all states had waiting periods. In many cases a worker injured for 5 weeks would receive no payment for the first 3 to 14 days of the disability, such that he might receive as few as 3 weekly payments. In a number of states, the worker would receive nothing during the waiting period, but if the disability lasted beyond 4 weeks (up to 7 weeks) the worker would eventually receive a retroactive payment for the first week or two of the disability. We have made our calculations sensitive to these nuances across states.

In a number of years the statutory parameters of the law changed. In those years we determined from the acts in each state when the new parameters went into effect and then used a weighted average of the benefits calculated under the old and the new law with the weight being the percentage of the time during the year that each law was in effect. The values in Table 2 do not follow this procedure and offer the benefits as they stood at the end of the year listed.

In the years prior to workers' compensation, the courts and settlements determined the payments to injured workers. Based on the material in Table I, we assumed that the family of a worker killed in a workplace accident could expect to receive about half a year's income on average (taking into account the probability of getting nothing). We then calculated the payment for a hand to be $\mathbf{5 4 . 0 2}$ percent of the fatal accident benefit and for the 5-week disability to be 1.557 percent of the fatal accident benefit. These percentages were based on national averages of the ratios of hand to death benefits and disability to death benefits from all states during the year 1923. It is clear that the generosity of the liability systems varied across states because insurance companies established state differentials for employers' liability premiums in their ratebooks. The state differentials would typically reflect differences in the liability rules and differences in the court treatments of accident compensation. The differentials are reported in DeLeon [1907, pp. 26-27]. To make this calculation we multiplied the benefits above by the state's reported liability differential and then divided by 0.64333 . The 0.64333 was the average liability differential reported for the 46 states plus Arizona and New Mexico (which were territories in 1909) in the sample. We also experimented with other payments under negligence liability. We tried giving a value of zero in all non-workers' compensation situations and we tried using the benefits without adjusting for the liability differential. The fundamental results remain the same.

The probabilities of an accident of each type were derived from different sources for each industry. In the coal industry we started with an average fatal accident rate of 2.043 per million man hours from the sample of coal states used to estimate the wage equation [Fishback 1992, p. 87]. To translate that into a fatal accident rate per full-year worked of 3.37 per 1000 men it was assumed that the men worked 206.4 8-hour days (from the sample means). The remaining coal accident rates were determined by comparing the relative number of fatal cases (61), permanent total disability cases (3), permanent partial disability cases (82), and temporary disability cases $(1,971)$ receiving compensation in coal mining from the Ohio State Insurance Fund during the 18 months ending June 30,1915 . For example, the permanent total disability probability is calculated as the probability of a fatal accident in coal mining $(0.0036)$ multiplied by the ratio of the number of permanent total disability cases to the number of fatal cases in Ohio (3/61). Using the Ohio workers' compensation information on cases compensated to estimate the probability of nonfatal accidents understates the actual probability of an accident since some injured workers were not compensated. The lumber and building trades accident rates were obtained from the Oregon Industrial Accident Commission [1919, pp. 28-42]. The Commission reported the total number of accidents in each accident category and the number of full time workers covered under 
the workers' compensation system. The accident probabilities underlying the index numbers in Table II are also from Oregon and represent the average accident experiences of all Oregon industries.

In calculating the expected benefits for the regressions we used the national average for each occupation for that year. We did not use the wage for the observation because the expected benefit would have been a function of the wage, imparting a positive bias to the coefficient for the observations where the worker did not hit the maximum. We could not use the ratio of expected benefits to wages because in the cases where benefits hit the maximum, it would impart a spurious negative bias. We chose the national average for the occupation in each year to allow the benefits to rise in response to the wage rise during the period. We have also experimented with using the real maximum expected benefits as an instrument for the expected benefits for all observations, and the results suggest a negative and statistically significant wage of fset in all cases. However, we did not focus on these results because the wages in many occupations were not high enough to hit the maximum. 